\title{
RESOLVING THE DURESS DILEMMA: GUIDANCE FROM THE HOUSE OF LORDS
}

\author{
Ray Ryan, Barrister-at-Law and Des Ryan, Balliol College, \\ Oxford $^{*}$
}

“. . . [Y]our Lordships should hesitate long lest you may be inscribing a charter for terrorists, gang-leaders and kidnappers." - Per Lord Simon of Glaisdale in Director of Public Prosecutions for Northern Ireland v Lynch [1975] AC 653, 688 .

\section{Introduction}

The defence of duress has long been regarded as a notoriously difficult area of the criminal law. Public policy considerations have demanded that for the defence to be successfully pleaded, a high threshold must be crossed. Beyond this, however, there is a paucity of clear guidance from the courts as to the situations in which a defence of duress will be successfully invoked by accused persons and there is thus a need for detailed consideration of the scope and rationale of the defence. With its decision in March 2005 in the case of $R$. v Hasan, ${ }^{1}$ the House of Lords has done much to bring greater clarity to the law on duress. The case is significant, inter alia, because the House expressly disapproved a decision of long standing with which criminal lawyers will be familiar, the Court of Appeal decision in $R \mathrm{v}$ Hudson and Taylor. ${ }^{2}$ Moreover, the House of Lords also considered the cases of Attorney General $\mathrm{v}$ Whelan ${ }^{3}$ and R. v Fitzpatrick, ${ }^{4}$ decisions of the former Irish Court of Criminal Appeal and the Northern Ireland Court of Criminal Appeal respectively. The authoritative formulation of the defence enunciated by Murnaghan $\mathrm{J}$ in Whelan has enjoyed a remarkable degree of endorsement across the common law world. ${ }^{5}$ In the recent Hasan case,

* The authors wish to thank Dr. John E. Stannard for his many very helpful suggestions and comments on an earlier draft. Any remaining errors are the sole responsibility of the authors.

1 [2005] UKHL 22; [2005] 2 WLR 709 (hereafter 'Hasan'). It should be noted that the appeal to the House of Lords in Hasan also involved an important question as to the meaning of a confession under the Police and Criminal Evidence Act 1984, addressed in the opinion of Lord Steyn, with which all of their Lordships agreed. For present purposes, however, our analysis is confined to the speeches of Lord Bingham of Cornhill and Baroness Hale of Richmond on the issue of duress. Lords Steyn, Rodger of Earlsferry and Brown of Eaton-under-Heywood agreed with the opinion of Lord Bingham.

2 [1971] 2 QB 202.

3 [1934] IR 518.

4 [1977] NI 20.

5 Examples include the approval of Whelan in the speeches of members of the Appellate Committee of the House of Lords in Director of Public Prosecutions for Northern Ireland v Lynch [1975] AC 653. Several Australian texts also refer to the judgment delivered by Murnaghan J, with Gillies regarding it as a "classic statement" (Gillies, Criminal Law ( $4^{\text {th }}$ ed., 1999, p.341); the case is also discussed, 
however, one aspect of the approach in Whelan has been disapproved. The House of Lords has firmly rejected the view, apparently espoused ${ }^{6}$ in Whelan, that the defence of duress can amount to a justification for the conduct of the accused; rather the defence is to be viewed as merely excusing the criminal conduct. Conversely, the Fitzpatrick decision has been roundly endorsed by the Appellate Committee in Hasan. More generally, it will be seen that the approach of the House of Lords in Hasan represents a policydriven response, aimed at confining this most controversial of defences within a restricted ambit. The purpose of the present article is to record the important observations of the Appellate Committee in this case, and to reflect on the potential influence that the decision may exert upon the operation of the defence of duress in criminal law.

\section{Hasan: The Background}

The facts of the Hasan case may be stated within a narrow compass. The defendant was charged with aggravated burglary, and relied on the defence of duress. He claimed to have been coerced into committing the burglary by one $\mathrm{S}$, a character known for his violent disposition and his involvement in dealing drugs. At his trial, the judge directed the jury that the accused could not rely on the defence of duress if, in their view, he had, by freely associating with $\mathrm{S}$, run the risk of being subjected to threats. The jury convicted the defendant. On his appeal to the Court of Appeal, ${ }^{7}$ the defendant's conviction was quashed, being regarded as unsafe on the basis that, inter alia, the judge had misdirected the jury on the issue of duress. Specifically, the Court of Appeal found fault with the refusal by the trial judge to direct the jury that the accused could rely on duress if they were satisfied that he had not anticipated that he would be compelled to commit a crime as serious as that of aggravated burglary. This approach was perhaps overly generous to accused persons who had chosen to consort with criminals and then sought to excuse their own criminality by stating that those criminals had coerced them into wrongdoing. Public policy, it might be objected, requires that the test for duress impose a more stringent standard on persons having recourse to this defence. It may not have come as much of a surprise then, that on the prosecutor's appeal, a unanimous House of Lords reversed the Court of Appeal, and restored the defendant's conviction.

\section{Judgment of the House of Lords}

In the House of Lords, the leading opinion was delivered by Lord Bingham, who conducted a detailed analysis of the history and rationale for the defence of duress as it has evolved and come to be understood over several centuries. Lord Bingham noted at the outset of his opinion the salient distinguishing features which set the defence apart from other defences available in the

albeit more critically, by Bronitt and McSherry, Principles of Criminal Law (2001), p.310.

6 The ambiguity surrounding this aspect of the Whelen formulation can be traced to the penultimate paragraph of the opinion of Murnaghan $J$ in that case, who at p.526 of the report employs, apparently interchangeably, the terms 'justification' and 'excuse'.

7 Rix LJ, Crane J and Judge Maddison: [2003] EWCA Crim 191; [2003] 1 WLR 1489 (sub nom $R \vee Z$ ). 
criminal law. These include the fact that it is now regarded as an excusatory, rather than a justificatory defence, a proposition for which his Lordship cited, inter alia, the decision of the House of Lords in Director of Public Prosecutions for Northern Ireland $\mathrm{v}$ Lynch. ${ }^{8}$ On this point, Lord Bingham considered the judgment of the former Irish Court of Criminal Appeal in Attorney General v Whelan, ${ }^{9}$ the classic Irish authority on the defence of the duress. In an oft-cited passage in his judgment in the Whelan case, Murnaghan J provided the following definition of the defence:

"It seems to us that threats of immediate death or serious personal violence so great as to overbear the ordinary power of human resistance should be accepted as a justification for acts which would otherwise be criminal." 10

In Hasan, Lord Bingham viewed this formulation as representing a now outmoded approach to the defence, since the better view now appears to be that the defence affords an excuse rather than a justification for unlawful conduct. ${ }^{11}$ Other distinguishing features of the defence which Lord Bingham emphasised included the fact that when successfully pleaded it acts as a complete, rather than a reductive, defence, totally exonerating the accused; that the victim may ordinarily be assumed to have been morally blameless; and that where the evidence is sufficient to raise the question of duress, the burden rests with the prosecution to establish to the criminal standard that the defendant did not act under duress. ${ }^{12}$ In light of these distinguishing features of the defence, Lord Bingham confessed that he found it "unsurprising that the law in this and other jurisdictions should have been developed so as to confine the defence of duress within narrowly defined limits", ${ }^{13}$ and even went so far as to observe that these very features of the defence inclined him

8 [1975] AC 653

9 [1934] IR 518.

10 ibid., at 526.

11 This criticism of the Whelan formulation had been hinted at by Lords Morris of Borth-y-Gest and Edmund-Davies in the course of their opinions in the Lynch case: [1975] AC 653, at 673 and 711 respectively. For valuable comment on the conceptual confusion that has prevailed in the case law see Smith, "Duress and Steadfastness: In Pursuit of the Unintelligible" [1999] Crim LR 363, 369. On the debate between adopting a justificatory or excusatory rationale in the context of the defence of duress generally see McAuley and McCutcheon, Criminal Law: A Grammar (2000), pp.786-817. In the course of her opinion in Hasan Baroness Hale noted that the "moral basis of the defence remains a hot topic" ([2005] UKHL 22, [73]), citing the recent article by Wilson, "The Structure of Criminal Defences" [2005] Crim LR 108.

12 Citing Director of Public Prosecutions for Northern Ireland v Lynch [1975] AC 653. As is well known, the Law Commission in its Report, Legislating the Criminal Code: Offences against the Person and General Principles (1993, Law Com. No 218, Cm 2370, paras.33-34), recommended that a legal burden of proof, on the balance of probabilities, be placed on a defendant to establish a defence of duress. Lord Bingham in his opinion in Hasan appeared to regard (at [20]) such a shift as a matter for the legislature and thus beyond the purview of judicial intervention, a point accepted by Baroness Hale - herself one of the signatories to the 1993 Report - at [74]. However, it is clear that the present position, imposing on the Prosecution the burden of disproving duress, comprises another reason for confining the operation of the defence within tight boundaries.

13 [2005] UKHL 22, [21]. 
"where policy choices are to be made, towards tightening rather than relaxing the conditions to be met before duress may be successfully relied on". ${ }^{14}$ His Lordship proceeded to enumerate no less than seven such limitations which have been placed on the ambit of the defence. ${ }^{15}$ The list is worth sketching out briefly:

1) Duress does not afford a defence to a charge of murder ${ }^{16}$ or attempted murder; ${ }^{17}$

2) The threat forming the basis of the duress must be one to cause death or serious personal injury;

3) The threat must be directed against the accused or his immediate family or a person close to him;

4) The test for establishing duress -unlike many other criminal law defences- is typically stated in objective terms;

5) The defence will only be available where the criminal conduct with which the accused is charged has been directly caused by the threats upon which he relies;

6) The accused must not have been in a position where a course of "evasive action" was open to him to take;

7) The accused cannot invoke the defence of duress where he has voluntarily laid himself open to that duress.

It is submitted that, of the above limitations on the defence, it is limitations 4 , 6 and 7 which are perhaps the most problematic, and it is therefore understandable that these elements received greatest treatment in the opinion of Lord Bingham. It is useful to analyse each in turn.

\section{Objectivity}

In considering the nature of the "objectivity" standard by which the criminal law adjudicates upon a defendant's plea of duress, two inquiries must be distinguished. The first concerns the determination of whether the accused was indeed motivated to act as he did out of fear that the threatened harm would be carried out if he failed to comply. On this point, Lord Bingham in Hasan approved the judgment of the Court of Appeal in R. v Graham, ${ }^{18}$ which had adopted a formulation of "reasonable belief". ${ }^{19}$ The objective element of the test adopted in Graham appears to have been somewhat diluted by the subsequent Court of Appeal decision in R. v Martin ${ }^{20}$, where Mantell LJ opined ${ }^{21}$ that, consistent with the Graham approach, the question

14 ibid., at [22].

15 ibid., at [21].

16 R. v Howe [1987] AC 417, noted Gearty, "Howe To Be A Hero" [1987] CLJ 203; Smith, "Must Heroes Behave Heroically?" [1989] Crim LR 622.

17 R. v Gotts [1992] 2 AC 412.

18 [1982] 1 WLR 294, approved by the House of Lords in $R$. v Howe [1987] AC 417.

19 [1982] 1 WLR 294, 300, per Lord Lane CJ.

20 [2000] 2 Cr App Rep 42.

21 ibid., at 49. 
of the defendant's reasonable belief could be judged in subjective terms. ${ }^{22}$ Perhaps surprisingly, Martin was not considered by Lord Bingham in his opinion in Hasan; it nevertheless seems correct to conclude that Mantell LJ's approach in that case cannot be reconciled with that of the Appellate Committee in Hasan.

Lord Bingham noted that the relevant Judicial Studies Board Direction, ${ }^{23}$ upon which the trial judge in Hasan had relied, contained the words "he genuinely believed", but made no reference to reasonableness. Lord Bingham explained that whilst it "is of course essential that the defendant should genuinely, i.e. actually, believe in the efficacy of the threat by which he claims to have been compelled", 24 this does not provide a "warrant for relaxing the requirement that the belief must be reasonable as well as genuine". ${ }^{25}$ It is perhaps salutary to recall that the distinction between a genuine and a reasonable belief is one which has proved not unproblematic in other areas of the criminal law, notably resurfacing of late in a series of Court of Appeal judgments concerning the drawing of adverse inferences from the silence of the accused under section 34 of the Criminal Justice and Public Order Act $1994 ;{ }^{26}$ the continued use of these overlapping, if not altogether tautologous, terms in the sphere of the objective test in duress, is to be regretted.

The second inquiry which, prior to Hasan, had remained unaddressed, was whether the defendant's foresight should be judged by an objective or subjective test, that is, does the defendant lose the benefit of a defence of duress only if he actually foresaw the risk of coercion or does he lose it if he ought reasonably to have foreseen the risk of coercion, whether he actually foresaw the risk or not? Whilst acknowledging that the application of an objective test to other elements of the defence of duress had attracted criticism, ${ }^{27}$ Lord Bingham nevertheless concluded that policy concerns pointed towards preferring an objective test. This is doubtless due to the distinguishing features of duress outlined by Lord Bingham at the outset of his opinion, features which in his Lordship's view rendered unhelpful analogies based on other defences such as self-defence and provocation. His Lordship thus answered the relevant certified question as follows:

"[T]he defence of duress is excluded when as a result of the accused's voluntary association with others engaged in criminal activity he foresaw or ought reasonably to have

22 His Lordship drew support for this position from the fact that Lord Lane CJ in Graham had drawn an analogy between duress by threats and self defence; he also relied on the then very recent decision of the Court of Appeal in $R$. v Cairns [1999] 2 Cr App Rep 137.

23 Direction No. 49, issued August 2000, available at http://www.jsboard.co.uk.

24 [2005] UKHL 22, [23].

25 ibid.

26 . v Betts and Hall [2001] EWCA Crim 224, [2001] 2 Cr App Rep 16; R. v Howell [2003] EWCA Crim 1, [2005] 1 Cr App Rep 1; R. v Hoare and Pierce [2004] EWCA Crim 784, [2005] 1 WLR 1804; R. v Beckles [2004] EWCA Crim 2766, [2005] 1 WLR 2829. For incisive comment see Barsby and Fitzpatrick [2005] Crim LR 560.

27 [2005] UKHL 22, [38]. 
foreseen the risk of being subjected to any compulsion by threats of violence." 28

This confirmation of the application of an objective test to these elements of the defence of duress is arguably one of the most important aspects of the Hasan decision. Landmark shifts towards subjectivity in the criminal sphere in recent years - the clearest example is perhaps $R$. $v G^{29}$ - might perhaps have given cause to conjecture that in the context of the defence of duress a subjective approach would ultimately be favoured. With its decision in Hasan, the House has robustly quelled any such speculation. The preservation of the objective standard is indicative of the hard line being taken towards the defence and rebuts any concern that the criminal law would resort to what has been termed a "sell-out to subjectivism". ${ }^{30}$

\section{The accused must not have been in a position where a course of "evasive action" was open to him to take}

Lord Bingham noted that the recent trend in the English authorities had been to emphasise the requirement that the accused should not have been capable of adopting a course of evasive action, his Lordship citing a well-known passage from the opinion of Lord Morris of Borth-y-Gest in Lynch. ${ }^{31}$ Lord Morris had cautioned that the defence of duress "must never be allowed to be the easy answer of those who can devise no other explanation of their conduct nor of those who readily could have avoided the dominance of threats nor of those who allow themselves to be at the disposal and under the sway of some gangster-tyrant". ${ }^{32}$ However, Lord Bingham expressed his concern that the requirement was one which had been "unduly weakened" 33 of late, and one of the most significant features of the Hasan ruling is its express repudiation of any such a tendency to dilute the strictness of this requirement.

The decision of the Court of Appeal in R. v Hudson and Taylor ${ }^{34}$ is one which will be familiar to criminal lawyers. The decision is popularly regarded as having embraced a generous view of the ambit of the duress defence: indeed, Lord Bingham in his opinion in Hasan notes Glanville Williams's description of Hudson and Taylor as "an indulgent decision". ${ }^{35}$ The appellants were two teenage girls who had committed perjury at an earlier trial by failing to identify the defendant. In the course of their trial for

28 ibid., at [39].

$29 R$. v $G$ [2003] UKHL 50; [2004] 1 AC 1034. In this judgment of a unanimous House of Lords, in which the leading opinion was again delivered by Lord Bingham, the notorious decision of the House in $R$ v Caldwell [1982] AC 341 was overruled. See Ryan and Ryan, "Recklessness, Subjectivity and the Criminal Law" (2004) 22 ILT (n.s.) 90; but see Kimel (2004) 120 LQR 548.

30 This phrase was employed by Horder in his analysis of the Law Commission's Report, above n.12; see Horder, "Occupying the Moral High Ground? The Law Commission on Duress" [1994] Crim LR 334, at 340.

31 [1975] AC 653.

32 ibid., at 670.

33 [2005] UKHL 22, [21].

34 [1971] 2 QB 202.

35 [2005] UKHL 22, [27] citing Williams, Textbook on Criminal Law ( $2^{\text {nd }}$ ed. 1983), p.636. 
perjury they pleaded duress on the basis that they had been warned by a group, including a man with a reputation for violence, that if they identified the defendant they would be killed. The trial judge ruled that the threats lacked sufficient immediacy to sustain the defence of duress: the girls could have sought the protection of the police, thereby "neutralising" the threat. This decision was reversed by the Court of Appeal, since although the threats could not be executed in the courtroom they could be carried out in the street that very same night. The Crown's argument that the appellants had failed to neutralise the threat by seeking police protection was rejected as failing to distinguish between cases in which the police would be in a position to provide effective protection and cases in which they would not.

Lord Bingham expressed his dissatisfaction with Hudson and Taylor in very clear terms:

"I can understand that the Court of Appeal. . . had sympathy with the predicament of the young appellants but I cannot, consistently with principle, accept that a witness testifying in the Crown Court at Manchester has no opportunity to avoid complying with a threat incapable of execution then and there. ${ }^{\prime 36}$

His Lordship further described the decision as having "had the unfortunate effect of weakening the requirement that execution of a threat must be reasonably believed to be imminent and immediate if it is to support a plea of duress". ${ }^{37}$ Thus, although not expressly overruled in Hasan, Hudson and Taylor was the subject of such disapproving comment as to effectively render the decision no more than a historical anomaly.

\section{The accused cannot invoke the defence of duress where he has voluntarily laid himself open to that duress}

It is well established that an accused person cannot invoke the defence of duress where he has voluntarily exposed himself to the threat of which he now complains. Indeed, in the course of her speech in Hasan, Baroness Hale said of this question that "[1] ogically, if it applies, it comes before all the other questions raised by the defence". ${ }^{38}$ The best-known authority in this regard is perhaps $R$. v Fitzpatrick. ${ }^{39}$ The accused was charged with murder, robbery and membership of a proscribed organisation. He was a member of the Official IRA, but testified that he had attempted to leave but had been prevented from doing so by threats of violence to himself and to his parents. At trial, the judge ruled that the defence of duress could not apply since the accused had voluntarily exposed himself to the threat. The Northern Ireland Court of Criminal Appeal upheld this decision, Lord Lowry LCJ explaining:

"This court is satisfied that there are circumstances in which persons who associate with violent criminals and voluntarily expose themselves to the risk of compulsion to commit criminal acts cannot according to the common law avail

36 [2005] UKHL 22, [27].

37 ibid.

38 ibid., at [74].

39 [1977] NI 20. 
themselves of the defence of duress...A person may become associated with a sinister group of men with criminal objectives and coercive methods of ensuring that their lawless enterprises are carried out and thereby voluntarily expose himself to illegal compulsion, whether or not the group is or becomes a proscribed organisation." 40

The approach in Fitzpatrick was arguably supported by dicta of members of the House of Lords in Lynch ${ }^{41}$ and was considered by Hutton $\mathrm{J}$ (as he then was) in the later case of $R$. v Calderwood. ${ }^{42}$ Calderwood and Moore, as members of a proscribed paramilitary group, had committed a murder. They sought to excuse their behaviour by reliance upon the defence of duress. It was held that that defence was not open to them, ${ }^{43}$ because by becoming members of an organisation whose objectives were criminal and coercive in nature, the defendants had chosen to expose themselves to the risk of illegal compulsion. Fitzpatrick was adopted by the English Court of Appeal in R. v Sharp, ${ }^{44}$ a decision cited with approval by Lord Bingham in Hasan. In Sharp, the appellant was a member of a gang which had carried out a series of armed robberies. He sought to plead duress as a defence to manslaughter when a sub-postmaster was shot dead by the gang ringleader in the course of a robbery. Sharp alleged that he had attempted to withdraw from this robbery when he realised that guns would be used, but that a gun had then been pointed at him and a threat made to "blow his head off" if he did not participate. Giving the judgment of the Court of Appeal, Lord Lane LCJ said:

“. . . [W]here a person has voluntarily, and with knowledge of its nature, joined a criminal organisation or gang which he knew might bring pressure on him to commit an offence and was an active member when he was put under such pressure, he cannot avail himself of the defence of duress." ${ }^{45}$

40 ibid., at 33.

41 [1975] AC 653. See for example the opinion of Lord Edmund-Davies at 705.

42 [1983] 10 NIJB.

43 Calderwood, of course, was decided at a time when there was some confusion as to whether the defence was considered to be available on a charge of murder. According to the House of Lords in Lynch, duress was available on the charge of murder to an accomplice or principal in the second degree, but in the course of its advice in Abbott v The Queen [1977] AC 755 the Judicial Committee of the Privy Council denied, by a majority, the defence to the principal in the first degree. However, while the two dissenting judges in Abbott, Lords Wilberforce and Edmund-Davies, had both been members of the majority in Lynch, of the judges in the majority in Abbott, only Lord Kilbrandon had formed part of the panel in Lynch, and his Lordship had in that case issued a terse dissent. Moreover, as Wilson shrewdly points out, the two minority judges in Abbott were "the only specialist criminal lawyers in the court" (Wilson, Criminal Law Doctrine and Theory, $2^{\text {nd }}$ ed., 2003, p.276). Thus Calderwood was decided against the backdrop of considerable uncertainty as to the availability of the defence of duress to an accused charged with murder. The point was not finally resolved till the unanimous decision of the House in Howe: see above n.16.

44 [1987] QB 853.

45 ibid., at 861 . It is apparent from the above passage that the criminal gang or organisation must be one likely to exercise duress and the accused must be aware 
However, the controversial question surrounding this limitation on the defence is whether it is sufficient for the prosecution to show merely that the accused knew that he might be compelled to participate in any form of criminal activity, or whether it must be shown that the accused was aware that he would be forced into committing a particular type of offence. The Court of Appeal in Hasan had taken the view that, in order for this restriction to operate so as to defeat the defence being available, the risk of compulsion of which the accused was aware must be related to "offences of the type charged". The underlying question for the jury to ask was thus, according to Rix LJ, "whether the accused anticipated that association with criminals could link him, even against his will, with criminality of the seriousness with which he is charged". ${ }^{46}$ On appeal, the House of Lords rejected this limitation. Lord Bingham noted that there had been "no warrant" for such a gloss on the voluntary association limitation until the judgment of the Court of Appeal in $R$. v Baker and Ward,$^{47}$ a judgment which his Lordship found not to have received widespread application or support in subsequent Court of Appeal decisions, ${ }^{48}$ and one which his Lordship ultimately concluded had "misstated the law". ${ }^{49}$ His Lordship expressed his rejection of the "type of offence" gloss on the voluntary association limitation in the following robust language:

"The defendant is seeking to be wholly exonerated from the consequences of a crime deliberately committed. The prosecution must negative his defence of duress, if raised by the evidence, beyond reasonable doubt. The defendant is, ex hypothesi, a person who has voluntarily surrendered his will to the domination of another. Nothing should turn on foresight of the manner in which, in the event, the dominant party chooses to exploit the defendant's subservience." ${ }^{50}$

Baroness Hale in her judgment, while agreeing with Lord Bingham, added an important (if obvious) qualification to the strictness of this approach. Baroness Hale stressed the importance of establishing that the accused had indeed set up "a voluntary association with others", stating that she did not believe this limitation on the defence to be aimed at such defendants as battered wives or those in close personal and family relationships with their duressors. ${ }^{51}$ For Baroness Hale, the other restrictions which operate on the defence of duress are "more than adequate to keep it within bounds in such cases". ${ }^{2}$

of this when he joins, as demonstrated by the Court of Appeal decision in $R$. v Shepherd (1988) 86 Cr App Rep 47.

46 [2003] EWCA Crim 191, [2003] 1 WLR 1489, [73].

47 [1999] 2 Cr App Rep 339.

48 R. v Heath [2000] Crim LR 109; R. v Harmer [2002] Crim LR 401.

49 [2005] UKHL 22, [37].

50 ibid.

51 ibid., at [78].

52 ibid. 


\section{Conclusion}

The defence of duress has rightly been described as "an extremely vague and elusive juristic concept". ${ }^{53}$ With its decision in the Hasan case, the House of Lords has provided a clear restatement of the law relating to the operation of the defence. It seems fair to describe the approach adopted by the Appellate Committee as one of extreme caution, predicated upon a fundamental unease with the operation of the defence and a consciousness of the need to guard against its potential abuse by an unworthy defendant. It is significant that the Appellate Committee regards the defence as entirely separate and distinct from the panoply of other defences in the criminal law: as Lord Bingham states, "[t]he only criminal defences which have any close affinity with duress are necessity, where the force or compulsion is exerted not by human threats but by extraneous circumstances, and, perhaps, marital coercion". ${ }^{4}$

The variety of reasons justifying such a restrictive approach to the ambit of the defence, as articulated by Lord Bingham in his opinion, undoubtedly give rise to concerns that the defence should not be developed beyond its strict parameters. Of particular note here is the apparent support of the Appellate Committee in Hasan for the notion that the strictness of these parameters can be supported when one bears in mind the fact that judges can have regard to the question of duress at the sentencing stage. ${ }^{55}$ Thus it appears that the focus towards the conceptual underpinnings of the defence is shifting back, at least in part, to the approach advocated by Lord Simon in his powerful dissenting judgment in Lynch, where his Lordship expressed the view that duress should go to mitigation, but not liability. ${ }^{56}$

The strictness of the course adopted in Hasan - most notably with regard to the rejection of a subjective test and the staunch adherence of the House to the Fitzpatrick doctrine - will doubtless be viewed by some as an overlyharsh response to the legitimate concerns tabulated by Lord Bingham. While it is undoubtedly the case that "the policy of the law must be to discourage association with known criminals, and it should be slow to excuse the criminal conduct of those who do so", ${ }^{57}$ will the approach adopted to the defence of duress generally in Hasan prove to have adequately resolved the duress dilemma?

53 Per Lord Simon of Glaisdale in the Lynch case: [1975] AC 653, 686.

54 [2005] UKHL 22, [19]. As to the impact of Hasan on the defence of necessity, it should be noted that Mance LJ (as he then was), speaking for a unanimous Court of Appeal in Quayle and ors v R. [2005] EWCA Crim 1415 was guided by the opinion of Lord Bingham in Hasan in adopting a similarly strict approach to the appellants' pleas of necessity of circumstances.

55 See especially the opinion of Lord Bingham at para.[22].

56 For comment see Glazebrook, "Committing Murder under Duress" [1975] CLJ 185.

57 Per Lord Bingham in Hasan [2005] UKHL 22, at [38]. 